\title{
Diversity and nitrogen fixation efficiency of rhizobia isolated from nodules of Centrolobium paraense
}

\author{
Alexandre Cardoso Baraúna(1), Krisle da Silva ${ }^{(2)}$, Gilmara Maria Duarte Pereira(3), Paulo Emílio Kaminski(2), \\ Liamara Perin ${ }^{(4)}$ and Jerri Edson Zilli( ${ }^{(5)}$ \\ (1)Universidade Federal de Roraima (UFRR), Campus Cauamé, BR-174, Km 12, Monte Cristo, CEP $69304-000$ Boa Vista, RR, Brazil. \\ E-mail: alexandre.barauna.bio@gmail.com (2)Embrapa Roraima, BR-174, Km 8, Distrito Industrial, CEP 69301-970 Boa Vista, RR, Brazil. \\ E-mail: krisle.silva@embrapa.br, paulo.kaminski@embrapa.br ${ }^{(3)}$ UFRR, Centro de Estudo da Biodiversidade, Campus do Paricarana, Avenida \\ Ene Garcez, oㅡ 2.413, CEP 69304-000 Boa Vista, RR, Brazil. E-mail: gmdpereira@hotmail.com (4)Instituto Federal de Sergipe, Campus \\ São Cristóvão, Rodovia BR-101, Km 96, Povoado Quissamã, CEP 49100-000 São Cristóvão, SE, Brazil. E-mail: liaperin@yahoo.com.br \\ ${ }^{(5)}$ Embrapa Agrobiologia, BR-465, Km 7, CEP 23891-460 Seropédica, RJ, Brazil. E-mail: jerri.zilli@embrapa.br
}

\begin{abstract}
The objective of this work was to isolate and characterize rhizobia from nodules of Centrolobium paraense and to evaluate their symbiotic efficiency. Soil samples collected from four sites of the Roraima Cerrado, Brazil, were used to cultivate C. paraense in order to obtain nodules. Isolates (178) were obtained from 334 nodules after cultivation on medium 79. Twenty-five isolates belonging to six morphological groups were authenticated using Vigna unguiculata and they were characterized by $16 \mathrm{~S}$ rRNA. Isolates identified as Bradyrhizobium were further characterized using rроB gene sequencing. A greenhouse experiment was carried out with $C$. paraense to test the 18 authenticated isolates. Approximately $90 \%$ of the isolates grew slowly in medium 79. The 16S rRNA analysis showed that 14 authenticated isolates belong to the genus Bradyrhizobium, and rpoB indicated they constitute different groups compared to previously described species. Only four of the 11 fast-growing isolates nodulated $V$. unguiculata, two of which belong to Rhizobium, and two to Pleomorphomonas, which was not previously reported as a nodulating genus. The Bradyrhizobium isolates ERR 326, ERR 399, and ERR 435 had the highest symbiotic efficiency on C. paraense and showed a contribution similar to the nitrogen treatment. Centrolobium paraense is able to nodulate with different rhizobium species, some of which have not yet been described.
\end{abstract}

Index terms: Bradyrhizobium, Rhizobium, bacteria diversity, biological nitrogen fixation.

\section{Diversidade e eficiência na fixação do nitrogênio de rizóbios isolados de nódulos de Centrolobium paraense}

Resumo - O objetivo deste trabalho foi isolar e caracterizar rizóbios de nódulos de Centrolobium paraense e avaliar sua eficiência simbiótica. Amostras de solo, coletadas de quatro locais do Cerrado de Roraima, foram utilizadas para o cultivo de $C$. paraense, para obtenção dos nódulos. Os isolados (178) foram obtidos dos 334 nódulos coletados após o cultivo em meio 79 . Vinte e cinco isolados, pertencentes a seis grupos morfológicos, foram autenticados com uso de Vigna unguiculata e caracterizados pelo 16S rRNA. Os isolados identificados como Bradyrhizobium foram caracterizados depois pelo sequenciamento do gene rpoB. Um experimento em casa de vegetação foi realizado com C. paraense, para testar os 18 isolados autenticados. Aproximadamente $90 \%$ dos isolados mostraram crescimento lento em meio 79. A análise do 16S rRNA mostrou que 14 dos isolados autenticados pertencem ao gênero Bradyrhizobium, e o rpoB indicou que eles constituem grupos diferentes em comparação às espécies já descritas. Somente quatro dos 11 isolados com crescimento rápido nodularam $V$. unguiculata, dois dos quais pertencentes a Rhizobium e dois a Pleomorphomonas, que não foi relatado anteriormente como gênero nodulífero. Os isolados de Bradyrhizobium ERR 326, ERR 399 e ERR 435 apresentaram a maior eficiência em C. paraense e mostraram contribuição similar ao tratamento nitrogenado. Centrolobium paraense é capaz de nodular com diferentes espécies de rizóbios, algumas das quais ainda não foram descritas.

Termos para indexação: Bradyrhizobium, Rhizobium, diversidade bacteriana, fixação biológica de nitrogênio.

\section{Introduction}

Centrolobium paraense Tul. (Fabaceae), commonly known as "pau-rainha", is a nodulating Neotropical leguminous tree occurring from the northern Brazilian Amazon to Panama, specifically in Roraima state (Pirie et al., 2009). It is present in semi-deciduous, gallery, and transition forests and is thought to play several

Pesq. agropec. bras., Brasília, v.49, n.4, p.296-305, abr. 2014

DOI: 10.1590/S0100-204X2014000400008 
ecological roles, which are essential to environmental sustainability, as increasing nutrient availability through biological nitrogen fixation (BNF), protecting against soil erosion, and acting as pioneer or early secondary species, which have also been reported for other Centrolobium species (Marques et al., 2001; Dahmer et al., 2009). In addition to its ecological importance, $C$. paraense has an economic and social importance because its wood is used by indigenous communities and industry (Dahmer et al., 2009; Pedreira, 2011). However, extractive exploration has been causing a gradual decrease in this plant resource, with an estimated decline of approximately $30 \%$ of the natural populations over the next years, demanding studies to increase the knowledge about this species and its conservation (Pirie et al., 2009).

Previous studies have indicated that $C$. paraense is capable of forming nodules with rhizobia native to the Amazon soil (Souza et al., 1994), but there are no published studies on the isolation and characterization of these rhizobia. Bacteria belonging to both genera Bradyrhizobium and Rhizobium have been reported to be able to establish symbioses with other species of Centrolobium, although studies have not been performed at the species level (Moreira et al., 1993; Pagano, 2008).

Cultural characteristics have been used for the initial characterization and screening of rhizobia; however, molecular techniques are necessary for a reliable characterization and identification. The 16S rRNA gene is the universal genetic marker most widely used for identification, classification and reconstruction of bacteria phylogeny. However, for identification of different rhizobia, the 16S rRNA gene sequencing is not suitable. For instance, in the genus Bradyrhizobium, the gene 16S rRNA presents a high degree of conservation among species, and sequence similarity is relatively high (Willems et al., 2001), limiting the species separation. However, housekeeping genes, which are involved in fundamental cell functions, came to be recommended to differentiate closely related species, including those within Bradyrhizobium genus, since they give a better resolution (Rivas et al., 2009).

Considering the ecological and economic importance of $C$. paraense, the isolation, characterization, and the symbiotic efficiency assessment of rhizobia is essential to develop inoculants for this legume.
The objective of this work was to isolate and characterize rhizobia from nodules of $C$. paraense and to evaluate their symbiotic efficiency.

\section{Materials and Methods}

Soil samples and seeds of Centrolobium paraense were collected in February 2010, which is the regional dry season, as well as $C$. paraense seed maturation season (Kaminski, 2004), at four different sites located on a private property, in four municipalities of the state of Roraima (Table 1). Five simple soil samples were collected at 0-20 cm depth, under the canopy of a Centrolobium paraense adult tree, at each site. The samples were combined into a composite sample of approximately $1 \mathrm{~kg}$ and were chemically characterized. Seed of the same plant were also collected for sowing as trap plant in the greenhouse. The soil samples were mixed with autoclaved sand $(1: 1)$ and placed in pots (approximately $3 \mathrm{~L}$ ) in triplicate. Centrolobium paraense seed were scarified with sulphuric acid (5 min), desinfected in 5\% hydrogen peroxide for 5 min, washed five times with sterilized water, and sown ( 5 seeds per pot), in soil samples of the same origin. Plant thinning was performed leaving two plants per pot. The experiment was carried out for 60 days using a completely randomized experimental design, and plants were watered with distilled water.

All the obtained nodules were disinfected with sodium hypochlorite $(5 \%)$, individually macerated, inoculated in Petri dishes containing culture medium 79 (Fred \& Waksman, 1928), and incubated for 10 days, at $28^{\circ} \mathrm{C}$. The resulting colonies were successively cultured in medium 79 until purification. Isolates were initially characterized in the same culture medium containing $0.05 \%$ bromothymol blue. Growth time, $\mathrm{pH}$ change of the culture medium, colony colour, shape, size, and mucus production were measured following Vincent (1970). These characteristics were used for clustering the isolates using Bionumerics (Applied Mathematics, Kortrijk, Belgium, v.6.1), with the Jaccard coefficient and UPGMA method.

Twenty-five isolates were selected, based on their distribution within the morphological groups; and considering the representativeness in each collecting sites. The isolates were inoculated in Vigna unguiculata because of this species has fast development and wide 
nodulation capacity with rhizobia from Amazon soils (Guimarães et al., 2012; Silva et al., 2012).

The experiment was performed in $500 \mathrm{~mL}$ recyclable amber glass bottles wrapped in aluminum foil with Hoagland nutrient solution (Hoagland \& Arnon, 1950) modified by Guimarães et al. (2012) at $1 / 4$ of ionic strength, with low nitrogen concentration (5.25 $\left.\mathrm{mg} \mathrm{L}^{-1}\right)$. Inoculants were prepared in liquid culture medium $79\left(5\right.$ days; $\left.28^{\circ} \mathrm{C}\right)$, and $1 \mathrm{~mL}$ inoculum, at approximately $10^{9}$ cell $\mathrm{mL}^{-1}$ concentration, was applied to each plant. A treatment without inoculation was included as a negative control, and a treatment inoculated with BR 3262 Bradyrhizobium commercial strain for $V$. unguiculata was included as a positive one. A completely randomized experimental design was used with three replicates.

All isolates inoculated on $V$. unguiculata were grown in culture medium 79, and genomic DNA was extracted using the RBC kit (catalogue number: YGB 300). Amplification of 16S rRNA gene was performed using the Y1 (Young et al., 1991) and B3 primers (Haukka, 1997), and partial sequencing was performed using the primer Y1. The sequencing was performed using a 3730xl DNA sequencer (Applied Biosystems, Foster City, CA, EUA).

For the 14 isolates that were similar to the genus Bradyrhizobium according to the 16S rRNA analysis, the gene $r p o B$ was also analyzed. DNA was amplified using the rpoB83F and rpoB1061R primers (Martens et al., 2008), followed by sequencing using the primer rpoB83F. Alignment, editing, and phylogenetic analysis were performed in Mega 5.05 (Tamura et al., 2011), using the neighbour-joining method (Saitou $\&$ Nei, 1987). The sequences were deposited in the GenBank (2014), and the accession numbers are given in Table 2.
After authentication, 18 isolates were tested for biological nitrogen fixation efficiency in $C$. paraense. This experiment was performed in a greenhouse $\left(28^{\circ} \mathrm{C}, 50 \%\right.$ reflective shade cloth) using a completely randomized experimental design with four replicates. Plants were grown in pots (7 L) containing autoclaved sand and vermiculite (2:1) as substrate. Centrolobium paraense seed collected from site III were scarified, desinfected (as described above), and pre-germinated in Petri dishes containing autoclaved moistened cotton and filter paper. Five days following germination, two seeds with approximately $1 \mathrm{~cm}$ long radicles were transplanted into each pot and inoculated with $1 \mathrm{~mL}$ bacterial suspension (as described above). In addition, two treatments inoculated with Bradyrhizobium japonicum and B. elkanii USDA $6^{\mathrm{T}}$ and USDA $76^{\mathrm{T}}$ strains, respectively, were included: one of the treatments had the addition of nitrogen $(\mathrm{N})$ as ammonium nitrate $(10 \mathrm{mg} \mathrm{N}$ per week from 0 to 28 days; $15 \mathrm{mg} \mathrm{N}$ per week from 29 to 70 days; $20 \mathrm{mg}$ $\mathrm{N}$ per week from 71 to 77 days; and $30 \mathrm{mg} \mathrm{N}$ per week from 78 to 91 days); and the other treatment was a negative control, without inoculation, and with a low nitrogen concentration. Each pot received $800 \mathrm{~mL}$ per week of nutrient solution adapted from Hoagland \& Arnon (1950), as above described, at $1 / 4$ of ionic strength for 42 days, $1 / 2$ of ionic strength for the following 35 days, and full ionic strength until the end of the experiment.

The measured variables were: shoot dry matter; root dry matter; number of nodules; nodule dry matter; total $\mathrm{N}$ content in the shoots, measured using the Kjeldahl method (Liao, 1981); leaf area, measured as the area of all leaflets using a LI - 3100 area meter (LI-COR, Lincoln, NE, EUA); plant height, measured from the base of the stem to the plant apex; and number of leaflets. Dry matter (of shoots, roots, and nodules) was

Table 1. Chemical analysis of collected soil samples from different phytophysiognomies at the Cerrado of the state of Roraima, Brazil.

\begin{tabular}{|c|c|c|c|c|c|c|c|c|c|}
\hline Site & Coordinates & Phytophysiognomies & $\mathrm{pH}$ & $\begin{array}{c}\mathrm{OM}^{(1)} \\
\left(\mathrm{g} \mathrm{dm}^{-3}\right)\end{array}$ & $\mathrm{Ca}$ & $\mathrm{Mg}$ & K & Al & $\begin{array}{c}\mathrm{P} \\
\left(\mathrm{mg} \mathrm{dm}^{-3}\right)\end{array}$ \\
\hline I & $3^{\circ} 25^{\prime} 11^{\prime \prime} \mathrm{N} ; 59^{\circ} 56^{\prime} 18^{\prime \prime} \mathrm{W}$ & Forest island & 5.8 & 19.5 & 1.57 & 0.67 & 0.21 & 0.01 & 1.68 \\
\hline II & $3^{\circ} 44^{\prime} 25^{\prime \prime} \mathrm{N} ; 59^{\circ} 40^{\prime} 9^{\prime \prime} \mathrm{W}$ & Gallery forest & 5.1 & 20.8 & 1.69 & 0.68 & 0.28 & 0.15 & 1.78 \\
\hline III & $2^{\circ} 43^{\prime} 40^{\prime \prime} \mathrm{N} ; 60^{\circ} 51^{\prime} 36^{\prime \prime} \mathrm{W}$ & Forest island & 4.9 & 20.8 & 1.35 & 1.06 & 0.15 & 0.66 & 1.68 \\
\hline IV & $2^{\circ} 27^{\prime} 13^{\prime \prime} \mathrm{N} ; 60^{\circ} 54^{\prime} 12^{\prime \prime} \mathrm{W}$ & Transition forest & 6.0 & 29.2 & 4.92 & 0.91 & 0.21 & 0.06 & 26.10 \\
\hline
\end{tabular}

${ }^{(1)} \mathrm{OM}$, organic matter. 
determined by drying the material at $65^{\circ} \mathrm{C}$ for 72 hours. The data were subjected to analysis of variance, and averages were compared using the Scott-Knott test, at $5 \%$ probability.

\section{Results and Discussion}

Nodules (334) were obtained using C. paraense as a trap plant. Nodule totals of the three replicates for each site - I through IV (Table 1) - were 94, 87, 20 , and 133, respectively. The soil characteristics and, more specifically, the higher soil organic matter, $\mathrm{Ca}$, and $\mathrm{P}$ concentrations, at site $\mathrm{IV}$, and the higher Al concentration, at site III, may have determined the differences in nodulation among sites, since these elements were reported as limiting for nodulation (Hungria \& Vargas, 2000). However, because the soil collection was performed during the dry season, and because there is usually higher rainfalls in forest/cerrado transition areas, the water availability may have also influenced soil-rhizobia population and, consequently, plant nodulation (Sadowsky, 2005).

Out of the 334 collected nodules, 178 isolates were obtained, 41 originating from the site I, 63 from site II, 10 from site III, and 64 from site IV. Therefore, isolates were obtained from 44 to $70 \%$ of the nodules from each soil sample. This variation

Table 2. Morphological groups, sampling areas, nodulation in Vigna unguiculata, and identification using 16S rRNA of rhizobia isolates obtained from Centrolobium paraense nodules from the Roraima Cerrado, Brazil.

\begin{tabular}{|c|c|c|c|c|c|c|c|c|c|}
\hline \multirow{2}{*}{$\begin{array}{l}\text { Morphological } \\
\text { group }^{(1)}\end{array}$} & \multirow{2}{*}{$\begin{array}{l}\text { Sampling } \\
\text { area }\end{array}$} & \multirow{2}{*}{$\begin{array}{l}\mathrm{N}^{\circ} \text { of } \\
\text { isolates }\end{array}$} & \multirow{2}{*}{$\begin{array}{c}\text { Isolates } \\
\text { authenticated }\end{array}$} & \multirow{2}{*}{$\begin{array}{l}\text { V. unguiculata } \\
\text { nodulation }\end{array}$} & \multirow{2}{*}{$\begin{array}{c}16 \mathrm{~S} \\
\text { Accession } \mathrm{n}^{\circ} .\end{array}$} & \multirow{2}{*}{$\begin{array}{c}r p o B \\
\text { Accession } \mathrm{n}^{\circ} .\end{array}$} & \multicolumn{3}{|c|}{ Most similar 16S rRNA sequence in GenBank } \\
\hline & & & & & & & Species & Accession $n^{\circ}$. & $\begin{array}{c}\text { Similarity } \\
(\%)\end{array}$ \\
\hline \multirow{4}{*}{1 (FAI) } & \multirow{4}{*}{ I, II } & \multirow{4}{*}{5} & ERR 333 & - & KF983821 & NA & Enterobacter $\mathrm{sp}$. & HM107175 & 99 \\
\hline & & & ERR 366 & - & KF983823 & NA & E. sacchari & HQ204281 & 99 \\
\hline & & & ERR 376 & - & KF983824 & NA & Pantoea agglomerans & JQ312027 & 99 \\
\hline & & & ERR 378 & - & KF983825 & NA & P. agglomerans & JQ312027 & 99 \\
\hline \multirow{4}{*}{2 (FAC) } & \multirow{4}{*}{ I, II } & \multirow{4}{*}{7} & ERR 308 & + & KF983816 & NA & Pleomorphomonas oryzae & AB681744 & 100 \\
\hline & & & ERR 344 & + & KF983817 & NA & P. oryzae & AB681745 & 98 \\
\hline & & & ERR 361 & - & KF983822 & NA & Enterobacteriaceae bacterium & EU887701 & 99 \\
\hline & & & ERR 469 & - & KF983826 & NA & Burkholderia kururiensis & FJ608710 & 100 \\
\hline \multirow{2}{*}{3 (FNC) } & \multirow[t]{2}{*}{ III } & \multirow[t]{2}{*}{3} & ERR 377 & + & KF983818 & NA & Rhizobium miluonense & KF515658 & 100 \\
\hline & & & ERR 380 & + & KF983819 & NA & R. miiluonense & KF515658 & 99 \\
\hline $4(\mathrm{SNC})$ & I, II & 3 & ERR 312 & - & KF983820 & NA & B. kururiensis & FJ608710 & 100 \\
\hline \multirow{4}{*}{5 (SALI) } & \multirow{4}{*}{ I, III, IV } & \multirow{4}{*}{25} & ERR 309 & + & KF983808 & KF983833 & Bradyrhizobium sp. & KF596702 & 99 \\
\hline & & & ERR 412 & + & KF983812 & KF983837 & Bradyrhizobium sp. & KF357630 & 99 \\
\hline & & & ERR 326 & + & KF927050 & KF983828 & Bradyrhizobium sp. & JQ419543 & 100 \\
\hline & & & ERR 329 & + & KF983809 & KF983834 & Bradyrhizobium sp. & KF596702 & 100 \\
\hline \multirow{10}{*}{6 (SALC) } & \multirow{10}{*}{$\begin{array}{l}\text { I, II, III, } \\
\text { IV }\end{array}$} & \multirow{10}{*}{135} & ERR 298 & + & KF983805 & KF983830 & Bradyrhizobium sp. & $\mathrm{KC} 113617$ & 100 \\
\hline & & & ERR 299 & + & KF983806 & KF983831 & Bradyrhizobium sp. & JQ419543 & 100 \\
\hline & & & ERR 305 & + & KF983807 & KF983832 & Bradyrhizobium sp. & JQ419544 & 100 \\
\hline & & & ERR 314 & + & KF927049 & KF983827 & Bradyrhizobium sp. & FJ193313 & 99 \\
\hline & & & ERR 396 & + & KF983810 & KF983835 & Bradyrhizobium sp. & KF357630 & 99 \\
\hline & & & ERR 399 & + & KF983811 & KF983836 & Bradyrhizobium sp. & KF357630 & 99 \\
\hline & & & ERR 417 & + & KF983813 & KF983838 & Bradyrhizobium sp. & KF596702 & 100 \\
\hline & & & ERR 421 & + & KF983814 & KF983839 & Bradyrhizobium sp. & $\mathrm{KC} 113617$ & 100 \\
\hline & & & ERR 430 & + & KF983815 & KF983840 & Bradyrhizobium sp. & KC113617 & 100 \\
\hline & & & ERR 435 & + & KF927051 & KF983829 & Bradyrhizobium sp. & KC113617 & 100 \\
\hline
\end{tabular}

FAI, fast-growing, medium acidification, and irregular colonies; FAC, fast-growing, medium acidification, and circular colonies; FNC, fast-growing, no pH medium alteration, and circular colonies; SNC, slow-growing, no pH medium alteration, and circular colonies; SALI, slow-growing, medium alkalinization, and irregular colonies; SALC, slow-growing, medium alkalinization, and circular colonies. NA, nonanalyzed. 
can be explained by the presence of many small nodules, apparently still in formation. Cultivation times longer than the tested 60 days may result in more fully formed nodules and in the recovery of a higher number of isolates. Characterization of the isolates, based on the morphology of colonies formed in culture medium 79 , showed that $90 \%$ of the isolates have characteristics which are typical of the genus Bradyrhizobium, such as slow growth (longer than five days), alkalinization and white colour of the colony and mucus (Jordan, 1982). Six morphological groups were obtained with $55 \%$ similarity, and groups V and VI comprised 160 isolates, all with slow growth (Table 2).

Twenty-five of the 178 rhizobia isolates $(15 \%$ of the total) were authenticated in $V$. unguiculata. Isolate selection was based on the morphological grouping and on the representativeness of the different sites in each group. Ten, eight, two, and five isolates were tested from sites I, II, III, and IV, respectively. From the 25 tested isolates, seven belonging to the morphological groups with only fast-growing isolates were not capable to promote $V$. unguiculata nodulation. In contrast, representatives of all groups containing slow-growing bacteria (14 isolates) and four fast-growing isolates formed nodules in $V$. unguiculata, indicating that more than $90 \%$ of the isolates were rhizobia.

Comparison of the partial 16S rDNA sequences, obtained for this study with the NCBI database (GenBank, 2014), showed that isolates with slow growing in the medium 79 and capable to form nodules on $V$. unguiculata belong to the genus Bradyrhizobium (Table 2). The isolates ERR 377 and ERR 380, highly similar to Rhizobium, and the ERR 308 and ERR 344, similar to Pleomorphomonas, were also capable to nodulate. From the remaining fast-growing isolates, three were grouped with Enterobacteriaceae, two with Burkholderia, and two with Pantoea, and none formed nodules on $V$. unguiculata. Isolates belonging to Enterobacteriaceae, Pantoea and Burkholderia have been reported as capable of colonizing nodules of different leguminous plants without, however, induce nodule formation (Saidi et al., 2011), although there are several Burkholderia nodulating species (De Meyer et al., 2013). This indicates that the non nodulating, cultured bacteria in the present study most likely grew in the culture medium before the rhizobia and were thus isolated. Strains ERR 378 and ERR
380 were not included in the phylogenetic analysis using 16S rDNA sequence (509 bp) because fewer than $500 \mathrm{bp}$ of the $16 \mathrm{~S}$ rDNA were obtained. The ERR 308 and ERR 344 fast-growing isolates were grouped with the type strains of Pleomorphomonas oryzae and $P$. diazotrophica, with high similarity, and strains ERR 377 and ERR 380 were grouped with $R$. tropici and $R$. miluonense, confirming that these strains belong to the genera Pleomorphomonas and Rhizobium, respectively (Figure 1). There are no previous reports on bacteria from the genus Pleomorphomonas forming nodules, although the three species described for this genus were indicated as capable to fix $\mathrm{N}$ in vitro (Xie \& Yokota, 2005; Im et al., 2006; Madhaiyan et al., 2013).

Fast-growing bacteria with similarity to Rhizobium have been previously found in nodules of Centrolobium plants (Moreira et al., 1993; Pagano, 2008), but symbionts of tropical leguminous plants predominantly belong to the genus Bradyrhizobium (Moreira et al., 1998). Bacteria of the genus Bradyrhizobium are reported as tolerant to low $\mathrm{pH}$ and fertility of tropical soils (Menna \& Hungria, 2011). The 14 slow-growing isolates were grouped into four different phylogenetic branches (Figure 1). Two isolates were grouped together with Bradyrhizobium group I type strains, which includes the traditional species B. japonicum (Delamuta et al., 2013), four strains with Bradyrhizobium group II, which includes $B$. elkanii, and two formed a group intermediate to Bradyrhizobium groups I and II.

The gene rроB analysis showed high genotypic diversity and polyphyletic distribution of the Bradyrhizobium isolates (Figure 2). Ten of the isolates were grouped with the $B$. iriomotense type strain EK $05^{\mathrm{T}}$, but with four subgroups, three of them with at least two isolates. The remaining four bacteria were grouped with $B$. elkanii and B. pachyrhizi, in agreement with which was observed for the 16S rDNA gene. Other works using $V$. unguiculata as a trap plant have shown the existence of Bradyrhizobium isolate groups from different sites in the Amazon region that are phylogenetically distant from species already described (Guimarães et al., 2012; Silva et al., 2012). Centrolobium paraense probably establishes symbioses preferentially with Bradyrhizobium species from Amazon soils, many of which have not yet been described, likely because 
Centrolobium is exclusively a Neotropical genus (Dahmer et al., 2009; Pirie et al., 2009). The analysis of $16 \mathrm{~S}$ rDNA and $r p o B$ genes have confirmed that the slow-growing isolates, obtained in the present study, belonged to the genus Bradyrhizobium, but that they constitute phylogenetic branches different from those of previously described species. Further taxonomic studies are needed for the confirmation of this hypothesis.

The strains USDA $6^{\mathrm{T}}$ and $76^{\mathrm{T}}$ formed only few nodules and did not promote plant growth compared with the negative control (Table 3). Similarly, inoculation with isolates ERR 308, ERR 309, ERR 421, ERR 430, ERR 377, ERR 305, ERR 299, ERR 344, and ERR 380 did not increase root or shoot dry matter compared with the control, although some nodulation and significant effects on some of the measured variables were observed. In contrast, isolates ERR 326, ERR 399, ERR 435, ERR 396, ERR 329, ERR 298, ERR 417, ERR 314, and ERR 412 significantly promoted accumulation of plant biomass which was similar to the treatment

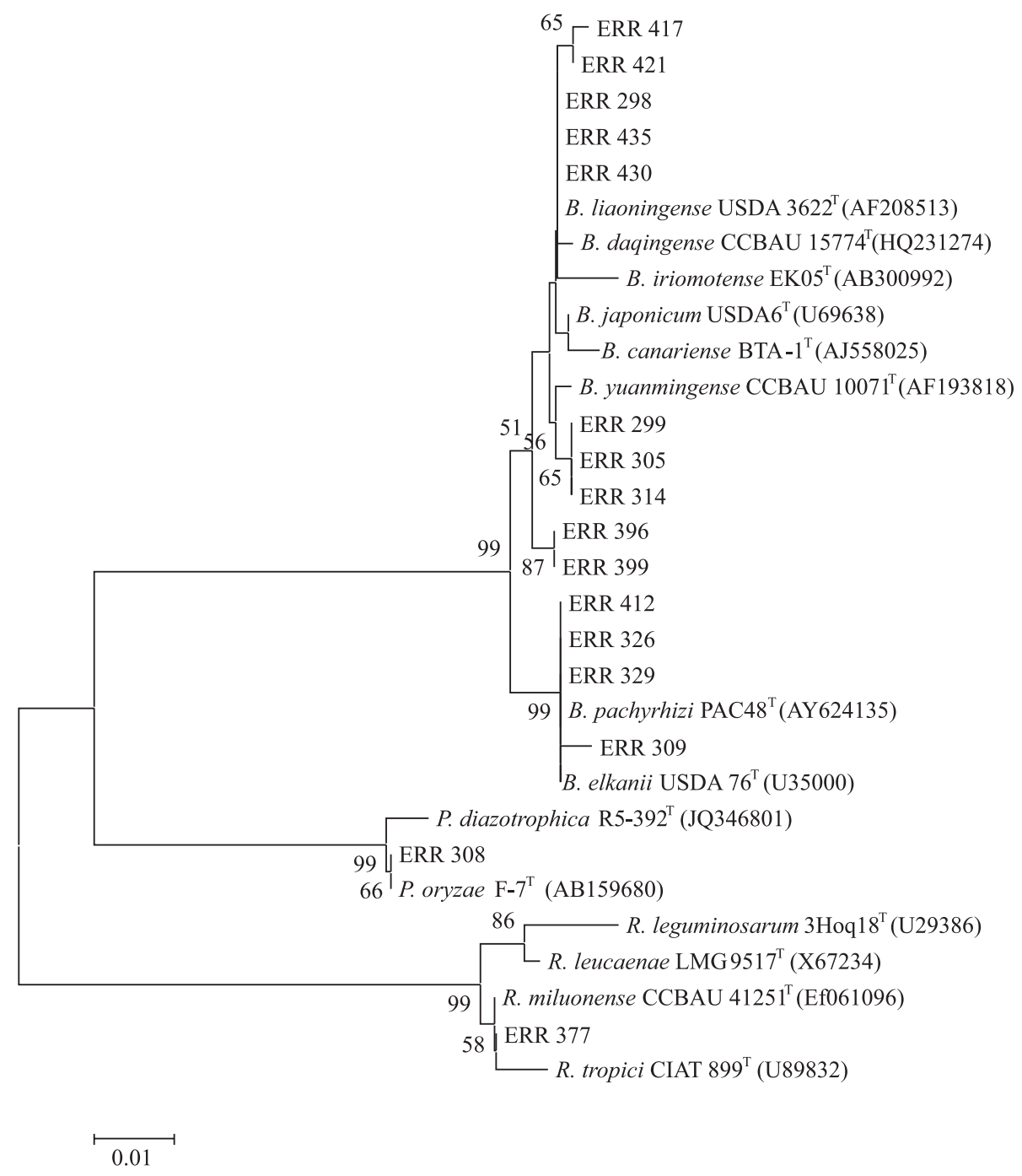

Figure 1. Neighbour-joining phylogeny, based on 16S rRNA gene sequences showing the relationships among rhizobium isolates obtained from Centrolobium paraense nodules (shown in bold) and other rhizobium type strains. Bootstrap values greater than $50 \%$ are indicated at the nodes. Bar indicates one substitution per 100 nucleotide positions. 
receiving mineral nitrogen. By nodulation and plant development results, it can be inferred a wide functional variability among rhizobia isolates for growth promotion in $C$. paraense plants, with the occurrence of high and low efficiency, irrespectively of the sample site (Table 2). There is an established population of rhizobia in the soils of the Roraima Cerrado, with efficient isolates that can contribute significantly to the development of $C$. paraense. Similarly, studies conducted with $C$. tomentosum have also shown variability in the symbiotic efficiency of native strains, and selected strains improved seedling development and plant establishment (Marques et al., 2001; Pagano, 2008).
Among the efficient isolates, ERR 326, ERR 399, and ERR 435 had more pronounced growth promotion effects on $C$. paraense because in addition to higher nodulation (number of nodules higher than 180, and nodule dry matter higher than $320 \mathrm{mg}$ per plant) and increasing biomass production (more than $7 \mathrm{~g}$ total dry matter, in 100 days), they also increase total $\mathrm{N}$ content in the shoots, leaf area, plant height and number of leaflets (Table 3). Therefore, as these three isolates belong to the genus Bradyrhizobium (indicated by $16 \mathrm{~S}$ rDNA and $r p o B$ gene), there is an indication that Bradyrhizobium strains are more efficient in BNF than fast-growing strains for $C$. paraense. These three isolates show high potential for use as inoculants for this host.

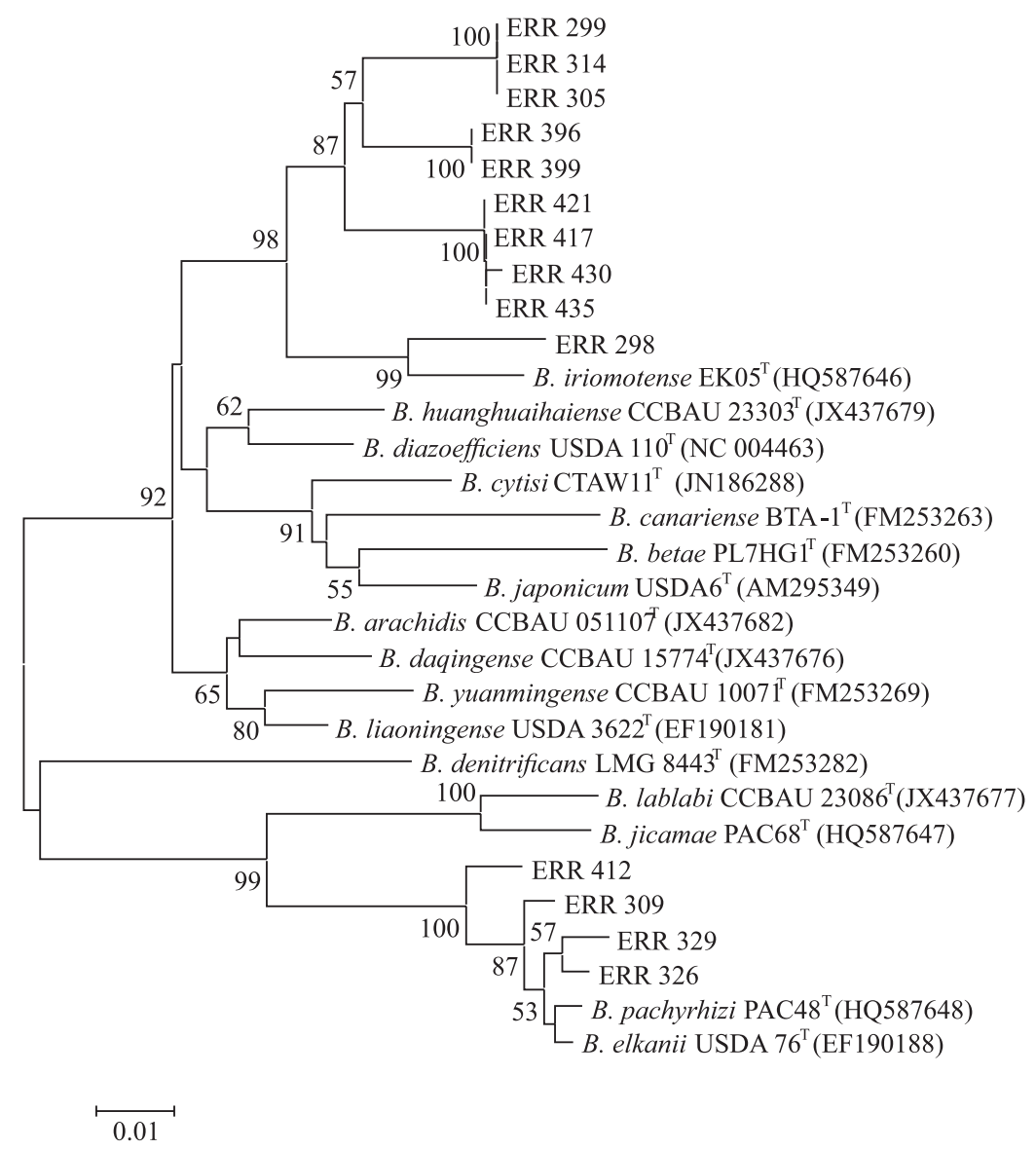

Figure 2. Neighbour-joining phylogeny, based on $r р о B$ gene sequences showing the relationships among Bradyrhizobium sp. isolates obtained from Centrolobium paraense nodules (shown in bold) and other Bradyrhizobium type strains. Bootstrap values greater than $50 \%$ are indicated at the nodes. Bar indicates one substitution per 100 nucleotide positions. 
Table 3. Shoot dry matter (SDM), root dry matter (RDM), number of nodules (NN), nodule dry matter (NDM), total N content in shoots (TNC), leaf area (LA), plant height (PH), and number of leaflets (NL) of pau-rainha (Centrolobium paraense Tul.) inoculated with soil-rhizobium isolates from the Roraima Cerrado, Brazil ${ }^{(1)}$.

\begin{tabular}{|c|c|c|c|c|c|c|c|c|c|}
\hline Site & Strain & $\begin{array}{c}\text { SDM } \\
\left(\text { g plant }^{-1}\right)\end{array}$ & $\begin{array}{c}\mathrm{RDM} \\
\left(\mathrm{g} \text { plant }{ }^{-1}\right)\end{array}$ & $\begin{array}{c}\mathrm{NN} \\
\left(\mathrm{N}^{\circ} \text { plant }^{-1}\right) \\
\end{array}$ & $\begin{array}{c}\text { NDM } \\
\left(\text { mg plant }^{-1}\right)\end{array}$ & $\begin{array}{c}\mathrm{TNC} \\
\left(\mathrm{mg} \mathrm{g}^{-1}\right)\end{array}$ & $\begin{array}{c}\text { LA } \\
\left(\mathrm{cm}^{2}\right)\end{array}$ & $\begin{array}{l}\mathrm{PH} \\
(\mathrm{cm})\end{array}$ & $\begin{array}{c}\mathrm{NL} \\
\left(\mathrm{N}^{\circ} \text { plant }^{-1}\right) \\
\end{array}$ \\
\hline I & ERR 326 & $4.9 \mathrm{a}$ & $2.7 \mathrm{a}$ & $191 \mathrm{a}$ & $326.3 a$ & $111.6 \mathrm{a}$ & $1408.3 \mathrm{a}$ & $17.3 \mathrm{a}$ & $21.8 \mathrm{a}$ \\
\hline III & ERR 399 & $4.7 \mathrm{a}$ & $2.5 \mathrm{a}$ & $212 a$ & $448.3 \mathrm{a}$ & $110.7 \mathrm{a}$ & $1268.6 a$ & $18.1 \mathrm{a}$ & $21.7 \mathrm{a}$ \\
\hline IV & ERR 435 & $4.7 \mathrm{a}$ & $2.4 \mathrm{a}$ & $187 \mathrm{a}$ & $320.2 a$ & $105.8 \mathrm{a}$ & $1224.1 \mathrm{a}$ & $17.0 \mathrm{a}$ & $19.5 \mathrm{a}$ \\
\hline III & ERR 396 & $4.4 \mathrm{a}$ & $2.2 \mathrm{a}$ & $126 \mathrm{~b}$ & $359.0 \mathrm{a}$ & $94.5 b$ & $1144.9 \mathrm{~b}$ & $19.5 \mathrm{a}$ & $20.7 \mathrm{a}$ \\
\hline I & ERR 329 & $4.3 \mathrm{a}$ & $2.0 \mathrm{a}$ & $159 b$ & $264.0 \mathrm{~b}$ & $98.4 \mathrm{~b}$ & $1196.6 \mathrm{a}$ & $21.2 \mathrm{a}$ & $21.8 \mathrm{a}$ \\
\hline II & ERR 298 & 4.1a & $2.1 \mathrm{a}$ & $74 \mathrm{c}$ & $225.4 \mathrm{~b}$ & $86.8 \mathrm{~b}$ & $1034.5 b$ & $18.9 \mathrm{a}$ & $19.8 \mathrm{a}$ \\
\hline IV & ERR 417 & $3.9 \mathrm{a}$ & $1.9 \mathrm{a}$ & $197 \mathrm{a}$ & $265.0 \mathrm{~b}$ & $87.6 \mathrm{~b}$ & $1064.9 \mathrm{~b}$ & $19.2 \mathrm{a}$ & $22.8 \mathrm{a}$ \\
\hline I & ERR 314 & $3.8 \mathrm{a}$ & $1.9 \mathrm{a}$ & $238 \mathrm{a}$ & $342.0 \mathrm{a}$ & $82.0 \mathrm{~b}$ & $1135.9 b$ & $20.3 \mathrm{a}$ & $18.2 \mathrm{~b}$ \\
\hline II & ERR 412 & $3.7 \mathrm{a}$ & $1.8 \mathrm{~b}$ & $191 \mathrm{a}$ & $295.1 \mathrm{~b}$ & $73.7 \mathrm{c}$ & $1032.8 \mathrm{~b}$ & $17.0 \mathrm{a}$ & $18.0 \mathrm{~b}$ \\
\hline I & ERR 308 & $3.4 \mathrm{~b}$ & $1.6 \mathrm{~b}$ & $133 b$ & $229.7 b$ & $82.9 \mathrm{~b}$ & $1035.2 \mathrm{~b}$ & $15.6 \mathrm{~b}$ & $20.5 \mathrm{a}$ \\
\hline I & ERR 309 & $3.1 \mathrm{~b}$ & $1.5 \mathrm{~b}$ & $215 \mathrm{a}$ & $350.8 \mathrm{a}$ & $67.7 \mathrm{c}$ & $1004.0 \mathrm{~b}$ & $17.7 \mathrm{a}$ & $21.3 \mathrm{a}$ \\
\hline IV & ERR 421 & $2.9 \mathrm{~b}$ & $1.4 \mathrm{~b}$ & $97 \mathrm{c}$ & $153.1 \mathrm{c}$ & $69.6 \mathrm{c}$ & $832.3 c$ & $15.5 b$ & $16.0 \mathrm{~b}$ \\
\hline IV & ERR 430 & $2.9 \mathrm{~b}$ & $1.2 \mathrm{~b}$ & $97 \mathrm{c}$ & $132.1 \mathrm{c}$ & $68.3 \mathrm{c}$ & $935.7 b$ & $15.1 \mathrm{~b}$ & $19.3 \mathrm{a}$ \\
\hline III & ERR 380 & $2.7 \mathrm{~b}$ & $1.8 \mathrm{~b}$ & $67 \mathrm{c}$ & $106.0 \mathrm{c}$ & $37.1 \mathrm{~d}$ & $726.1 \mathrm{c}$ & $16.2 \mathrm{a}$ & $14.6 \mathrm{~b}$ \\
\hline II & ERR 344 & $2.8 \mathrm{~b}$ & $1.6 \mathrm{~b}$ & $26 \mathrm{~d}$ & $104.0 \mathrm{c}$ & $51.1 \mathrm{c}$ & $799.0 \mathrm{c}$ & $13.9 \mathrm{~b}$ & $17.3 b$ \\
\hline III & ERR 377 & $2.5 \mathrm{~b}$ & $1.5 \mathrm{~b}$ & $3 d$ & $15.3 \mathrm{~d}$ & $37.5 \mathrm{~d}$ & $670.7 \mathrm{c}$ & $11.8 \mathrm{~b}$ & $15.1 \mathrm{~b}$ \\
\hline I & ERR 305 & $2.3 b$ & $1.0 \mathrm{~b}$ & $122 b$ & $155.3 \mathrm{c}$ & $56.3 \mathrm{c}$ & $808.0 \mathrm{c}$ & $15.3 b$ & $18.2 \mathrm{~b}$ \\
\hline I & ERR 299 & $2.3 b$ & $1.3 \mathrm{~b}$ & $113 b$ & $168.1 \mathrm{c}$ & $52.2 \mathrm{~d}$ & $658.0 \mathrm{c}$ & $12.9 \mathrm{~b}$ & $16.8 \mathrm{~b}$ \\
\hline- & USDA $6^{\mathrm{T}}$ & $2.4 \mathrm{~b}$ & $1.5 \mathrm{~b}$ & $7 \mathrm{~d}$ & $32.1 \mathrm{~d}$ & $36.9 \mathrm{~d}$ & $654.9 \mathrm{c}$ & $11.4 \mathrm{~b}$ & $15.2 \mathrm{~b}$ \\
\hline- & USDA $76^{\mathrm{T}}$ & $2.0 \mathrm{~b}$ & $1.2 \mathrm{~b}$ & $2 d$ & $8.9 \mathrm{~d}$ & $30.8 \mathrm{~d}$ & $571.3 \mathrm{c}$ & $9.8 b$ & $14.7 \mathrm{~b}$ \\
\hline- & Control & $2.4 \mathrm{~b}$ & $1.4 \mathrm{~b}$ & - & - & $38.9 \mathrm{~d}$ & $614.0 \mathrm{c}$ & $12.3 b$ & $13.1 \mathrm{~b}$ \\
\hline- & Nitrogen & $5.3 \mathrm{a}$ & $2.6 \mathrm{a}$ & - & - & $129.9 \mathrm{a}$ & $1348.2 \mathrm{a}$ & $20.8 \mathrm{a}$ & $23.3 \mathrm{a}$ \\
\hline CV (\%) & & 20.69 & 22.39 & 25.89 & 29.70 & 23.31 & 15.87 & 18.00 & 17.44 \\
\hline
\end{tabular}

${ }^{(1)}$ Means followed by equal letters within columns do not differ, by Scott-Knott test, at $5 \%$ probability.

\section{Conclusions}

1. Centrolobium paraense is able to nodulate with different rhizobia species, including some not yet described.

2. Rhizobia belonging to the genus Bradyrhizobium are the most common root-nodulating-bacteria for C. paraense.

3. Some rhizobia isolated from $C$. paraense exhibit high biological nitrogen fixation efficiency for this host.

\section{References}

DAHMER, N.; WITTMAN, M.T.S.; KAMINSKI, P.E. Chromosome number and karyotype of the endangered Amazonian woody Centrolobium paraense Tul. species. Crop
Breeding and Applied Biotechnology, v.9, p.382-385, 2009. DOI: 10.12702/1984-7033.v09n04a13.

DE MEYER, S.E.; CNOCKAERT, M.; ARDLEY, J.K.; MAKER, G.; YATES, R.; HOWIESON, J.G.; VANDAMME, P. Burkholderia sprentiae sp. nov., isolated from Lebeckia ambigua root nodules. International Journal of Systematic and Evolutionary Microbiology, v.63, p.3950-3957, 2013. DOI: 10.1099/ijs.0.048777-0.

DELAMUTA, J.R.M.; RIBEIRO, R.A.; ORMEÑO-ORRILLO, E.; MELO, I.S.; MARTÍNEZ-ROMERO, E.; HUNGRIA, M. Polyphasic evidence supporting the reclassification of Bradyrhizobium japonicum group la strains as Bradyrhizobium diazoefficiens sp. nov. International Journal of Systematic and Evolutionary Microbiology, v.63, p.3342-3351, 2013. DOI: 10.1099/ijs.0.049130-0.

FRED, E.B; WAKSMAN, S.A. Yeast extract-mannitol agar for laboratory manual of general microbiology. New York: McGraw Hill, 1928. 145p. 
GENBANK. Available at: <http://www.ncbi.nlm.nih.gov/ Genbank>. Accessed on: 12 Feb. 2014.

GUIMARÃES, A.A.; JARAMILLO, P.M.D.; NÓBREGA, R.S.A.; FLORENTINO, L.A.; SILVA, K.B.; MOREIRA, F.M.S. Genetic and symbiotic diversity of nitrogen-fixing bacteria isolated from agricultural soils in the western Amazon by using cowpea as the trap plant. Applied and Environmental Microbiology, v.78, p.6726-6733, 2012. DOI: 10.1128/ AEM.01303-12.

HAUKKA, K. Genetic diversity and phylogeny of rhizobial isolated from tropical tree legumes. 1997. 94p. Thesis (Ph.D.) - University of Helsinki, Helsinki, Finlandia.

HOAGLAND, D.R.; ARNON, D.I. The water-culture method for growing plants without soil. Berkeley: University of California, 1950. 32p. (California Agricultural Experiment Station. Circular, 347).

HUNGRIA, M.; VARGAS, M.A.T. Environmental factors affecting $\mathrm{N}_{2}$ fixation in grain legumes in the tropics, with an emphasis on Brazil. Field Crops Research, v.65, p.151-164, 2000. DOI: 10.1016/S0378-4290(99)00084-2.

IM, W.-T.; KIM, S.-H.; KIM, M.K.; TEN, L.N.; LEE, S.T. Pleomorphomonas koreensis sp. nov., a nitrogen-fixing species in the order Rhizobiales. International Journal of Systematic and Evolutionary Microbiology, v.56, p.1663-1666, 2006. DOI: 10.1099/ijs.0.63499-0.

JORDAN, D.C. Transfer of Rhizobium japonicum Buchanan 1980 to Bradyrhizobium gen. nov., a genus of slow-growing, root nodule bacteria from leguminous plants. International Journal of Systematic Bacteriology, v.32, p.136-139, 1982. DOI: 10.1099/00207713-32-1-136.

KAMINSKI, P.E. O pau-rainha (Centrolobium paraense): características, potencialidades e usos. Boa Vista: Embrapa Roraima, 2004. 31p. (Embrapa Roraima. Documentos, 10).

LIAO, C.F.H. Devarda's alloy method for total nitrogen determination. Soil Science Society of America Journal, v.45, p.852-855, 1981. DOI: $10.2136 /$ sssaj 1981.03615995004500050 $005 \mathrm{x}$.

MADHAIYAN, M.; JIN, T.Y.; ROY, J.J.; KIM, S.J.; WEON, H.Y.; KWON, S.W.; JI, L. Pleomorphomonas diazotrophica sp. nov., an endophytic N-fixing bacterium isolated from root tissue of Jatropha curcas L. International Journal of Systematic and Evolutionary Microbiology, v.63, p.2477-2483, 2013. DOI: 10.1099/ijs.0.044461-0.

MARQUES, M.S.; PAGANO, M.; SCOTTI, M.R.M.M.L. Dual inoculation of a woody legume (Centrolobium tomentosum) with rhizobia and mycorrhizal fungi in South-Eastern Brazil. Agroforestry Systems, v.52, p.107-117, 2001. DOI: 10.1023/A:1010637401475.

MARTENS, M.; DAWYNDT, P.; COOPMAN, R.; GILLIS, M.; DE VOS, P.; WILLEMS, A. Advantages of multilocus sequence analysis for taxonomic studies: a case study using 10 housekeeping genes in the genus Ensifer (including former Sinorhizobium). International Journal of Systematic and Evolutionary Microbiology, v.58, p.200-214, 2008. DOI: 10.1099/ijs.0.65392-0.
MENNA, P.; HUNGRIA, M. Phylogeny of nodulation and nitrogen-fixation genes in Bradyrhizobium: supporting evidence for the theory of monophyletic origin, and spread and maintenance by both horizontal and vertical transfer. International Journal of Systematic and Evolutionary Microbiology, v.61, p.3052-3067, 2011. DOI: 10.1099/ijs.0.028803-0.

MOREIRA, F.M.S.; GILLIS, M.; POT, B.; KERSTERS, K.; FRANCO, A.A. Characterization of rhizobia isolated from different divergence groups of tropical Leguminosae by comparative polyacrylamide gel electrophoresis of their total proteins. Systematic and Applied Microbiology, v.16, p.135-146, 1993. DOI: 10.1016/S0723-2020(11)80258-4.

MOREIRA, F.M.S.; HAUKKA, K.; YOUNG, J.P.W. Biodiversity of rhizobia isolated from a wide range of forest legumes in Brazil. Molecular Ecology, v.7, p.889-895, 1998. DOI: 10.1046/j.1365294x.1998.00411.x.

PAGANO, M.C. Rhizobia associated with Neotropical tree Centrolobium tomentosum used in riparian restoration. Plant Soil and Environment, v.54, p.498-508, 2008.

PEDREIRA, J.L. Uso e manejo de pau-rainha (Centrolobium paraense Tul. - Fabaceae) na terra indígena Araçá, RR. 2011. 91p. Dissertação (Mestrado) - Instituto Nacional de Pesquisa da Amazônia, Manaus.

PIRIE, M.D.; KLITGAARD, B.B.; PENNINGTON, R.T. Revision and biogeography of Centrolobium (Leguminosae Papilionoideae). Systematic Botany, v.34, p.345-359, 2009. DOI: $10.1600 / 036364409788606262$.

RIVAS, R.; MARTENS, M.; DE LAJUDIE, P.; WILLEMS, A. Multilocus sequence analysis of the genus Bradyrhizobium. Systematic and Applied Microbiology, v.32, p.101-110, 2009. DOI: $10.1016 /$ j.syapm.2008.12.005.

SADOWSKY, M. Soil stress factors influencing symbiotic nitrogen fixation. In: WERNER, D.; NEWTON, W. (Ed.). Nitrogen fixation in agriculture, forestry, ecology, and the environment. Dordrecht: Springer, 2005. p.89-112. DOI: 10.1007/1-4020-3544-6_6.

SAIDI, S.; MNASRI, B.; MHAMDI, R. Diversity of nodule-endophytic agrobacteria-like strains associated with different grain legumes in Tunisia. Systematic and Applied Microbiology, v.34, p.524-530, 2011. DOI: 10.1016/j. syapm.2011.01.009.

SAITOU, N.; NEI, M. The neighbor-joining method: a new method for reconstructing phylogenetic trees. Molecular Biology and Evolution, v.4, p.406-425, 1987.

SILVA, F.V.; SIMÕES-ARAÚJO, J.L.; SILVA JÚNIOR, J.P.; XAVIER, G.R.; RUMJANEK, N.G. Genetic diversity of rhizobia isolates from Amazon soils using cowpea (Vigna unguiculata) as trap plant. Brazilian Journal of Microbiology, v.43, p.682-691, 2012. DOI: $10.1590 / \mathrm{S} 1517-83822012000200033$.

SOUZA, L.A.G. de; SILVA, M.F. da; MOREIRA, F.W. Capacidade de nodulação de cem leguminosas da Amazônia. Acta Amazonica, v.24, p.9-18, 1994. 
TAMURA, K.; PETERSON, D.; PETERSON, N.; STECHER, G.; NEI, M.; KUMAR, S. MEGA5: molecular evolutionary genetics analysis using maximum likelihood, evolutionary distance, and maximum parsimony methods. Molecular Biology and Evolution, v.28, p.2731-2739, 2011. DOI: 10.1093/molbev/msr121.

VINCENT, J.M. A manual for the practical study of root-nodule bacteria. Oxford: Blackwell Scientific, 1970. $164 \mathrm{p}$.

WILlEMS, A.; COOPMAN, R.; GILLIS, M. Phylogenetic and DNA-DNA hybridization analyses of Bradyrhizobium species.
International Journal of Systematic and Evolutionary Microbiology, v.51, p.111-117, 2001.

XIE, C.H.; YOKOTA, A. Pleomorphomonas oryzae gen. nov., sp. nov., a nitrogen-fixing bacterium isolated from paddy soil of Oryza sativa. International Journal of Systematic and Evolutionary Microbiology, v.55, p.1233-1237, 2005. DOI: 10.1099/ijs.0.63503-0.

YOUNG, J.P.W.; DOWNER, H.L.; EARDLY, B.D. Phylogeny of the phototropic Rhizobium strain BTAil by polymerase chain reaction-based sequencing of a $16 \mathrm{~S}$ rDNA gene segment. Journal of Bacteriology, v.173, p.2271-2277, 1991.

Received on February 11, 2014 and accepted on March 14, 2014 